University of Nebraska - Lincoln

DigitalCommons@University of Nebraska - Lincoln

Faculty Publications, Department of History

History, Department of

Spring 2013

\title{
"In Family Way": Guarding Indigenous Women’s Children in Washington Territory
}

Katrina Jagodinsky

University of Nebraska-Lincoln, kjagodinsky@unl.edu

Follow this and additional works at: https://digitalcommons.unl.edu/historyfacpub

Part of the Feminist, Gender, and Sexuality Studies Commons, Legal Commons, Other American Studies Commons, Social History Commons, United States History Commons, and the Women's History Commons

Jagodinsky, Katrina, "'In Family Way": Guarding Indigenous Women’s Children in Washington Territory" (2013). Faculty Publications, Department of History. 142.

https://digitalcommons.unl.edu/historyfacpub/142

This Article is brought to you for free and open access by the History, Department of at DigitalCommons@University of Nebraska - Lincoln. It has been accepted for inclusion in Faculty Publications, Department of History by an authorized administrator of DigitalCommons@University of Nebraska - Lincoln. 


\title{
"In Family Way"
}

\author{
Guarding Indigenous Women's Children
}

in Washington Territory

KATRINA JAGODINSKY

Just two years after losing her Danish father, Coast Salish mother, and métis sisters to an undocumented tragedy in 1877 , Nora Jewell faced another tragic ordeal. ${ }^{1}$ The twelve-year-old cleared fields and mended fences for James Smith, a guardian appointed by the court to protect her body and estate until she reached eighteen or married. As Nora confided to her maternal aunt Ellen Jones, however, Smith repeatedly assaulted her in the marshy grasslands of central San Juan Island, a secret she would have kept had he not put her "in family way" by the age of fourteen. Ellen's immigrant husband encouraged his niece to report Smith's crimes to the justice of the peace. The ensuing trial revealed that Nora had been placed with Edward Boggess, an elderly and crippled bachelor whom islanders deemed untrustworthy, and then with James Smith, a married homesteader who earned his living by farming, mining, and performing odd jobs. Witnesses described Smith as a strict master who limited Nora's social interactions with Salish relatives, schoolmates, and potential suitors and put her to hard physical labor on his homestead. Nevertheless, the jury of Smith's peers acquitted the workingman, apparently in reasonable doubt of Smith's abuses and paternity and seemingly convinced that Nora's mixed-race and fatherless background proved her promiscuity. ${ }^{2}$

Salishan tribes valued lateral kinship, and without a territorial court to claim jurisdiction over her, Nora would most likely have joined Ellen Jones's household after losing her parents. ${ }^{3}$ With her maternal aunt's family in such close proximity, it is worth asking why the orphan was placed under the care of men unrelated to her. Trial testimony suggests that the judge who brokered Nora's guardianship favored Indian assimi- 
lation, which explains why he put the girl in white homes that could benefit from her productive and reproductive labors rather than placing her with Ellen Jones's métis family. Twelve years old when she lost her family, Nora had also reached the age of sexual consent established in the territory. ${ }^{4}$ Widely circulated newspaper articles such as "Marriage Made Easy" indicate that some residents viewed guardianship as a means to overcome the gap between the age of consent (twelve) and the age of majority (eighteen) so guardians could marry their own wards. ${ }^{5}$ Legislators had reversed the territory's earlier ban on marriages between white men and métis women, and Probate Justice Bowman may have seen an orphaned mixed-race girl as the ideal child-bride for an aging homesteader like Edward Boggess; indeed, some witnesses would later testify that they suspected it was Boggess who had impregnated the orphaned ward. ${ }^{6}$ In 1877, however, Nora lived just three months in Boggess's home before Judge Bowman revoked his guardianship without explanation and assigned the girl to James Smith, likely because he was married and deemed less predatory. Smith put his ward to work in the fields, where he could abuse her beyond the perimeter of his home and the purview of his wife, using guardianship as a means to exploit Nora's economic and sexual vulnerability on an island and in a region still engaged in the violent transition from Indian country to American state, one household at a time. ${ }^{7}$

Nora Jewell's compelling story is told at greater length elsewhere in my work, but this article's concern is the role of nineteenth-century guardianship practices as a pivotal phase in the larger history of formal and informal indigenous child removal. ${ }^{8}$ Nora Jewell's painful experiences mirror the larger history of settler-colonialism in the Puget Sound region, and they began when Washington's territorial guardianship law defined her as a ward of the state because she had been orphaned. As they collectively stripped Nora Jewell of dignity, family, and property, Probate Judge John Bowman, guardians Ed Boggess and James Smith, and Washington territorial jurists practiced the "microtechniques of dispossession" outlined by Paige Raibmon, who argues that "colonialism's network of laws, attitudes, and practices placed" interracial families like Nora Jewell's "at the center of the transformation and transfer of lands" from indigenous to settler ownership. ${ }^{9}$ Established as a territory apart from Oregon in 1853, Washington attracted hundreds and then thousands of homesteaders, loggers, miners, and traders before the fed- 
eral government could negotiate land cession treaties with local tribes. ${ }^{10}$ Though many newcomer men like Nora's father and uncle forged intimate and life-long relationships with indigenous women and their families, the large-scale invasion of armed and entitled Americans on unceded lands prompted the Puget Sound Indian Wars of 1855 to 1858 , and violent skirmishes continued throughout the territorial period between citizens convinced of their land claims and indigenous people equally assured of their sovereign tenancy. ${ }^{11}$

Indigenous mothers, caught up in violent land disputes and the denigration of Indian people that followed coercive treaty negotiations, struggled to maintain custody of their children. Once the territorial legislature mandated the appointment of guardians for minors whose parents were deemed "unsuitable" caretakers, Native mothers suffered yet another gendered onslaught of dispossession. Like other guardianship and "poor laws" designed to protect the interests of orphaned children and ensure that they did not become public dependents, the guardianship statute required that probate courts appoint guardians to wards until they reached the age of majority (eighteen for girls, twenty-one for boys). Though written as a law to protect orphaned children and their estates, territorial Washington's guardianship statute put Native women's children on an open market for any and all "friends" and "uninterested parties" and allowed petitioners to attack indigenous women's maternal capacity and moral character. ${ }^{12}$

As applied by Judge Bowman and James Smith, the guardianship statute closely resembled the more overtly exploitative minor Indian indenture laws practiced in other portions of the North American West during this period. ${ }^{13}$ Such laws allowed citizens to claim the productive and reproductive labors of indigenous women's children without parental consent. Less predatory settler-colonists in Washington Territory used informal guardianship practices to gain access to aboriginal children's labors and loyalties. In her memoir, "A Pioneer's Search for an Ideal Home," Phoebe Goodell Judson recorded her extralegal acquisition of no less than seven children of indigenous mothers. ${ }^{14}$ The widespread practice of informal indigenous child removal is documented in many recent histories of the North American West, though not all refer to these practices as explicitly as others. ${ }^{15}$ Judson's sentimental memoir of her pioneering years, published in 1925, perfectly illustrates Jacobs's characterization of "maternal colonialism," a program of racial 
uplift and domestic assimilation based in white maternal authority and middle-class feminism. ${ }^{16}$ Smith's use of the guardianship system for coercive labor and sexual predation contrasts with Judson's view of guardianship as a philanthropic tool for assimilation, but both Puget Sounders reflected the broad range of nineteenth-century attitudes toward the proper place of indigenous and métis people in American homes and society. ${ }^{17}$

The guardianship system that entrapped Nora Jewell comprised an intermediate phase between racially specific indenture laws that allowed westering Americans to exploit unfree labor in the nineteenth century, and racially specific adoption practices that allowed progressive Americans to exploit a still-colonized population in the twentieth century. Nineteenth-century indenture laws fixed race and power by marking wards as nonwhite by the very nature of their indenture, defining wards as the Indian dependents of their white masters. Twentiethcentury adoption practices obscured race and power by erasing children's tribal and familial lineage and promoting affectionate bonds of assimilation. Guardianship, as a transitional system between coercive indenture and covert adoption, promoted racial-ethnic ambiguity and interracial intimacy - consensual and otherwise-and allowed for creative structuring and obscuring of kinship. Based on the decisions of local jurists and neighbors, sometimes casual and occasionally codified, temporary and transferable, guardianship proved to be a remarkably flexible system. Guardianship in territorial Washington served the interests of pioneering men looking to exploit a child labor market and appealed to westering women who practiced maternal colonialism and applauded their own contributions to métis children's racial uplift, but it also allowed indigenous people to maintain family ties otherwise unrecognized in territorial courts. Despite the capacity of citizens to use the guardianship system to denigrate indigenous maternal authority and exploit the productive and reproductive labors of minor Indians, Native women still managed to use guardianship to gain parental authority over their children, and adolescent mixed-race girls petitioned courts to evade the advances of predatory men.

Having begun with Nora Jewell's tragic experiences in territorial Washington's guardianship system, the remainder of this essay chronicles the experiences of other wards able to avoid such extreme outcomes. Their stories include those who used guardianship to dodge the harrow- 
ing realities of colonialism as their family members lost their land to homesteaders and taxes and lost their kin to epidemics, starvation, and racial violence. Others gained a basic education in guardians' homes and avoided federal boarding schools, allowing them to remain within their home communities, intermarry with métis and Indian neighbors, and reclaim tribal lands through allotment and homestead provisions. Some chose guardianship as a transformative mechanism that allowed them to reinvent themselves as white citizens, thus gaining access to rights and privileges their guardians enjoyed. Still others used guardianship to maintain family ties and made wards of their cousins, nephews, nieces, and siblings before men like Ed Boggess or James Smith could claim them on the child market that the guardianship system effectively codified. Petitioners' access to and familiarity with métis and Native minors and their mothers proves the interracial density of territorial Washington's nineteenth-century communities. Though not all guardianship arrangements were documented, and many failed to mention the racial-ethnic identities of minor wards or petitioners, the handful of cases collected here offer a deeper understanding of indigenous child removal practices prior to the institutionalization of formalized adoption programs in the American West and provide evidence of métis and Indian families' efforts to gain leverage within an exploitative system. ${ }^{18}$

Guardianship allowed some children to dodge the sexual and economic vulnerability that the system had actually facilitated in Nora Jewell's case. In 1863 the editor of the Puget Sound Times, Charles Prosch, petitioned for the guardianship of "a certain halfbreed girl living at O. H. White's . . aged about eight years, known by the name of Susan Suckley. ... There are being efforts made by certain irresponsible parties to take the said girl to the mining country the other side of the mountains which in the opinion of your petitioner is a very improper place for a girl. ... Further ... I have been informed that O. H. White does not wish to keep her longer. Your petitioner would therefore ask to be appointed Guardian of the aforesaid child." ${ }^{19}$ A man convinced that mixed-race progeny of Indian and white unions "possess not only all the vices inherent in the Indian, but unite with them the bad qualities of the whites," the journalist nevertheless acted to ensure Susan would not be trafficked into borderlands mining camps where she would undoubtedly have endured hardship if not also abuse. ${ }^{20}$ Ezra Meeker, prominent advocate and employer of noted Puyallup families in the Tacoma 
region, cosigned Prosch's guardianship bond, and Susan Suckley never appeared in census schedules for the journalist's household, suggesting that Susan might have been informally returned to indigenous kin once Prosch obtained legal guardianship. ${ }^{21}$ Though none mention Susan specifically, many Puyallup Indian Agency records from the 188 os and 189 os describe Indian officials' confusion over mixed-race allotment applicants with ambiguous ties to the Puyallup tribe that required lengthy explanation. Their correspondence indicates that Puyallup families negotiated their own extralegal adoptions and guardianships among and between stepparents and extended kin beyond the purview of Indian and territorial officials. ${ }^{22}$

A rare example of a mixed-race minor filing her own request for a guardian shows that some children of Indian mothers used guardianship to escape relationships that were already abusive. In 1881 Mary Margaret Toary asked an Olympia probate judge to assign Thomas Hinchcliffe, a dairyman with a daughter near Mary's age, as her legal guardian. ${ }^{23}$ The sixteen-year-old reported that "her father [was] dead and she [did] not know where her mother" was, that she had lived with John DeLacatom since she was four and that he had "never made any proper provision for [her] support and education ... or discharged the duties of a natural guardian towards here, but on the contrary ... made criminal proposals to [her] and ... attempted to coerce [her] to live with him against her consent." ${ }^{24}$ The judge appointed English-born Hinchcliffe as Mary's guardian, and the mixed-race girl was attending school with other Olympia children within a few months. ${ }^{25}$ Susan's and Mary's cases suggest that Nora Jewell's abusive situation was not uncommon for young and adolescent métis girls caught up within territorial Washington's guardianship system, whether their parents were alive or not. Nineteenth-century epidemics in the Puget Sound region, fluid and shifting identity, and international mobility help to explain the disappearance of mixed-race children's parents, but most cases prove silent regarding the actual fates of Indian mothers. ${ }^{26}$

As their parents struggled to survive colonial conquest, some guardianship arrangements offered minor Indians and mixed-race children a temporary respite from the disruptions of federal and territorial Indian policies until they reached adulthood, when they could opt to rejoin their indigenous communities or-because of the racial-ethnic malleability of the guardianship system — claim a new identity based in white- 
ness. Of course, these choices were contextual and dynamic, resulting in multiple articulations and expressions of racial-ethnic identity in the course of an individual lifetime. Puget Sound pioneer Phoebe Judson described a boy she presumed was orphaned because he traveled with elderly women and men:

We judged by his size that he was about ten years old, and unusually bright for an Indian boy, soon learning our . . . language and making himself useful in many ways.... He seemed quite pleased with his new name [Jack Judson], and also with his new home, living with us until he was able to support himself by working for wages. . . A lady who is acquainted with Jack and his family writes me that "he is a Christian and as white as anyone," meaning that he is a good citizen. ${ }^{27}$

Though his guardian was convinced that Jack had transformed from heathen to Christian, Indian to white, and ward to citizen during the years he spent in her "ideal home," Jack Judson continued to affirm his indigeneity in adult years, marrying a Chehalis-Tenino woman and reporting his Nisqually-Satsop lineage to enumerators. Until his death in 1919, Jack and his wife, Mary, shared their home with an extended indigenous and métis family that reflected their lifelong maintenance of intimate bonds with Native kin. ${ }^{28}$

Other of Judson's mixed-race charges maintained shifting racialethnic identities in adulthood, suggesting that Indian women's children exercised considerable agency in electing and expressing both indigeneity and whiteness in turn-of-the-century Washington. Dollie and Nellie Patterson, daughters of Col. James Patterson and Indian woman Lizzie, crafted a white identity that secured them the privileges of state-sanctioned marriage and maternal custody when they reached adulthood in the $188 \mathrm{os}^{29}$ The four children of Daniel McClanahan and Nooksack woman Nina joined the Judson household when their father begged Phoebe to "take charge of his children and find comfortable homes for them in white families." ${ }^{30}$ Nina died shortly after her husband, and her daughter Nora would die in the Judson home at age twenty. ${ }^{31}$ Nora's brother Horace Greeley married a white woman from New York, and together they raised three métis children on their farm in Whatcom County. Horace and his children appeared as alternately "white" and "Indian" in twentieth-century census schedules, suggesting 
that he and enumerators renegotiated his identity from year to year, perhaps depending on local sentiments toward Indian and métis community members, which could be alternately nostalgic and volatile. ${ }^{32}$

In a gesture typical of practitioners of maternal colonialism, Phoebe Judson maintained that Lizzie and Nina, the mothers of the Patterson and McClanahan children, not only approved of her guardianship but were grateful to her for caring for their progeny. ${ }^{33}$ Very few guardianship cases included Native mothers' endorsement of petitioners, however, and were more likely to cite indigenous maternity as the justification for appointing a guardian to métis children whose white fathers had died or disappeared. In many of these cases petitioners for guardianship promised to protect métis children-primarily girls under thirteen-from the ills of Indianness ("a life of Prostitution and Asking" or "living on the beach, as in the manner of her people") and described individual mothers almost universally as "an Indian woman wholly unqualified and incompetent to the care, maintenance, and education" of her progeny. Some petitioners went further, claiming that Native mothers practiced immoral and lewd behavior that endangered their children. Such rhetoric generally coincided with popular Victorian attitudes toward Native women, degraded by their sexual relationships with and economic dependency on immoral white men, but a closer look reveals that many Native and interracial petitioners manipulated jurists' racial and gendered biases and stereotypes against Indian mothers in order to obtain custody of their own siblings, cousins, nephews, and nieces. ${ }^{34}$

Italian-born farmer James Frank told the court in 1876 that Matilda Reuny was "a bright, likely girl, and capable of making a good and useful woman in the Country." ${ }^{35}$ The immigrant explained that his wife, Sophia, was Matilda's sister and expressed his concern that their indigenous mother might raise eight-year-old Matilda "to a life of Prostitution and 'Asking."' The probate judge granted the Frank family's petition, and four years later Matilda and Sophia's brother Fred was also living with them in Clallam County. Throughout the 188 os, Sophia and James also raised mixed-race girl Angelina Williams to adulthood, though her relationship to the Franks is undocumented. ${ }^{36}$ William Newton reported in 1864 that Caroline Dunning's Clallam mother, Cecilia, was "of bad habit and given to drunkenness" and that her white father, John Dunning, had recently died. Using language outlined in the guardianship statute itself, Newton claimed to be "a friend of Caroline Dunning" in his petition, 
but he did not disclose that he and his wife, Annie, were also Clallam. The probate judge in Port Townsend awarded the Newtons guardianship of their métis ward, and Caroline spent ten years with William and Annie before she married Leon Stevens. ${ }^{37}$ Caroline's guardians continued to raise their own and informally adopted children among Clallam and Puyallup neighbors and relatives into the twentieth century, once again demonstrating indigenous families' dexterous use of extralegal and legal strategies to maintain and validate kinship ties. ${ }^{38}$

In Matilda's and Caroline's cases, métis and indigenous relatives managed to gain custody of children who might otherwise have grown up in abusive households like James Smith's or assimilationist homes like Phoebe Judson's. Rather than waiting for relatives or strangers to make claims upon her mixed-race children once her white husband died, Celia Fitzgerald petitioned the court in 1878 to make Matt Fleming the guardian of her four children. Celia adopted the language other petitioners used and "acknowledged herself as an Indian woman incapable of administering properly upon the property of said minors," and the court granted her petition. ${ }^{39}$ Celia married Matt Fleming sometime in the late 1870 , and this guardianship petition likely helped to ensure her métis family's economic and legal security during a period when miscegenation statutes fluctuated according to legislators' own habits and moods. Unfortunately for this proactive woman, the master's tools would not help her after 1886, when she divorced Fleming and the court refused to revoke his guardianship of her children. ${ }^{40}$ Fitzgerald's mixedrace progeny maintained the family bonds she sought to protect in the guardianship system, however, and continued living together in the Jamestown Village along with neighbors William and Annie Newton for the first quarter of the twentieth century. Not able to retain legal authority over her family, Celia Fitzgerald nonetheless managed to preserve their indigeneity. ${ }^{41}$

The cases discussed here represent very few of the guardianship arrangements that characterized intergenerational and interracial households in territorial Washington, yet the patterns they illustrate correspond with other evidence that allows historians to track the distribution of Indian and mixed-race children in the Puget Sound region. The 1880 federal census schedules for counties bordering the Puget Sound reveals the informal guardianship of Native women's children in ninetytwo households. Among these extralegal arrangements were forty-two 
households headed by white men, some single like Ed Boggess and others married to white women like Phoebe Judson, who classified the indigenous and/or métis minors in their homes as "adopted" children or as boarders, laborers, and servants. Thirty-five interracial households housed children not fathered by the white head of household but related in some way to adult Indian women in the home. Like the Franks and the Fitzgeralds, these métis families reported minor wards as extended kin-nieces, in-laws, and cousins - and occasionally as family "visitors" or "adopted" children. Fourteen indigenous households reported children not their own, usually as extended kin or simply as children with other surnames, leaving their relationships undefined, as William and Annie Newton did. Though these households comprise a mere 1 percent of those enumerated in Puget Sound counties, they affirm that citizen, métis, and Native families valued the economic and emotional labors Indian women's children provided. Some of these household heads no doubt exploited the minors in their homes, using them much as indentured servants, while others ensured their survival at the peak of settlercolonist dispossession in the Pacific Northwest, treating them much like their own kin. In combination with the guardianship cases discussed above, they also affirm the flexibility of guardianship as a localized and temporary arrangement, and they confirm métis and Native families' ability to use guardianship as a means to retain custody of minor relatives. Among the arrangements formalized in probate courts and reported in census schedules, the slim majority of children found homes in interracial or Indian households. For this reason, proponents of racial uplift and tribal assimilation could not possibly have found the guardianship system an effective tool of colonization. ${ }^{42}$

Collectively, these cases demonstrate that Native and métis families managed to use guardianship as a means to navigate the shifting categories of race and power during the early stages of settler-colonialism before federal interventions accelerated and institutionalized indigenous child removal. Though children like Nora Jewell suffered the extreme abuses that the guardianship system could orchestrate, the flexible nature of guardianship allowed other wards to escape potential abuse and exploitation, to retain ties to indigenous communities and relatives, and to appropriate racial-ethnic fluidity during Washington's territorial period. As Indian officials became more concerned with documenting family lineage and managing tribal membership rolls and allotment pat- 
ents, extralegal and flexible guardianship arrangements would diminish, and federal officials, philanthropic organizations, and social welfare agents joined forces to institutionalize indigenous child removal and absolve Native maternal authority. ${ }^{43}$ As the twentieth-century studies in this issue reveal, indigenous mothers and their families would find ways to resist those systems of dispossession as well. ${ }^{44}$

\section{ACKNOWLEDGMENTS}

I would like to thank Margaret Jacobs for organizing a workshop at the 2011 Berkshire Conference of Women Historians and the participants for their insightful comments on an early draft, in addition to the archivists at the Washington State Archive, the National Archives and Records Administration in Seattle, and the Center for Pacific Northwest Studies in Bellingham, and my Puget Sound hosts Julie Lucht and Nik Siefter, Megan Prins and Andy Low, and Guard and Connie Sundstrom. This article has been generously supported by the Clements Center for Southwest Studies at Southern Methodist University and the Gender and Women's Studies Department, History Department, and Social and Behavioral Sciences Research Institute at the University of Arizona. It is part of a manuscript in progress on indigenous women's encounters with colonial legal regimes in the Pacific Northwest and Sonoran Southwest between 1854 and 1935 .

\section{NOTES}

1. The term "métis" is used interchangeably with "mixed-race" to denote persons with indigenous and white backgrounds and should not be read as a specifically French and Indian racial mixture or as reference to the Métis people formally recognized by the Canadian government.

2. Territory of Washington v. James Smith (1880), Jefferson County Territorial Criminal Case \#1088, Washington State Archives Northwest Regional Branch. A more in-depth analysis of Nora Jewell's family history and trials is offered in my forthcoming manuscript. Nora's tribal origins are difficult to determine from the documentary record, but her mother's and aunt's residency on San Juan Island suggests possible affiliations with a number of Puget Sound tribes, including the Lummi and Saanich; for a description of bands claiming San Juan Island, see Carroll Riley et al., Coast Salish and Western Washington Indians, vol. 2 (New York: Garland Publishing, 1974); and Julie K. Stein, Exploring Coast Sal- 
ish Prehistory: The Archaeology of San Juan Island (Seattle: University of Washington Press, 2000). For ethnohistories of these and other tribes discussed in this article, see Robert H. Ruby and John Brown, A Guide to the Indian Tribes of the Pacific Northwest (Norman: University of Oklahoma Press, 1986); and William C. Sturtevant and Wayne P. Suttles, Handbook of North American Indians, vol. 7, Northwest Coast (Washington DC: Smithsonian Institution, 1990).

3. For a discussion of Salish kinship, see the editor's introduction in Bruce Granville Miller, ed., Be of Good Mind: Essays on the Coast Salish (Vancouver: University of British Columbia Press, 2007), 1-29; and general references to Salishan practices in a study focused on the Skagit by June McCormick Collins, "The Influence of White Contact on Class Distinctions and Political Authority among the Indians of Northern Puget Sound," in Riley et al., Coast Salish, $113-23$.

4. For age of consent law, see Seventh Regular Session Laws of Washington Territory, 1859, 109, available online via Hein Online Session Laws Library, http:// heinonline.org/hol/Page?men_tab=srchresults\&handle=hein.ssl/sswa0127 \&size $=2 \&$ collection $=$ ssl\&set_as_cursor $=9109 \&$ $\&$ id $=109$.

5. "Marriage Made Easy," Puget Sound Weekly (Seattle wA), January 28, 1867; "Marriage Made Easy," Walla Walla (wA) Statesman, September 18, 1869.

6. Miscegenation laws varied considerably during Washington's territorial period, ranging from no ban in 1853 , when the territory was formed, to an outright ban on Indian-white unions in 1855, recognition of marriages between mixed-race and white partners, and finally a return to race-neutral marital statutes by 1881 . In addition to the statutes themselves, available through Making of Modern Law and Hein Online Session Law Library databases, see Greg Russell Hubbard, "The Indian under the White Man's Law in Washington Territory, 1853-1889" (MA thesis, University of Washington, Seattle, 1972), 48-51; Peyton Kane, "The Whatcom Nine: Legal and Political Ramifications of Metis Family Life in Washington Territory," Columbia Magazine 14, no. 2 (Summer 200o): 39-44; Peggy Pascoe, What Comes Naturally: Miscegenation Law and the Making of Race in America (New York: Oxford University Press, 2009), 98-103.

7. Readers should consider the families described in this article as part of the legal and social contexts more fully historicized in Brad Asher, Beyond the Reservation: Indians, Settlers, and the Law in Washington Territory, 1853-1889 (Norman: University of Oklahoma Press, 1999); Andrew H. Fisher, Shadow Tribe: The Making of Columbia River Indian Identity (Seattle: University of Washington Press, 2010); Alexandra Harmon, Indians in the Making: Ethnic Relations and Indian Identities around Puget Sound (Berkeley: University of California Press, 1998); Paige Raibmon, Authentic Indians: Episodes of Encounter from the Late-Nineteenth-Century Northwest Coast (Durham: Duke University Press, 2005); and Coll Thrush, Native Seattle: Histories from the Crossing-Over Place (Seattle: University of Washington Press, 2007). 
8. Nora lived the remainder of her life in the Puget Sound region, occasionally with her métis cousins, though her child was never documented. In 1890 she sold her land on San Juan Island, likely because the site of her rapes remained visible from the Jewell homestead. Her story comprises a chapter of my in-progress manuscript on indigenous women's encounters with colonial legal regimes in the second half of the nineteenth and early twentieth centuries.

9. Paige Raibmon, "Unmaking Native Space: A Genealogy of Indian Policy, Settler Practice, and the Microtechniques of Dispossession," in The Power of Promises: Rethinking Indian Treaties in the Pacific Northwest, ed. Alexandra Harmon (Seattle: University of Washington Press, 2008), 56-85.

10. For ethnohistories of these and other tribes discussed in this article, see Ruby and Brown, A Guide to the Indian Tribes; and Sturtevant and Suttles, Northwest Coast.

11. For a general history, see Robert E. Ficken, Washington Territory (Pullman: Washington State University Press, 2002).

12. Statutes of the Territory of Washington, Being the Code Passed by the Legislative Assembly, at Their First Session Begun and Held at Olympia, February 27th, 1854: Also Containing the Declaration of Independence, the Constitution of the United States, the Organic Act of Washington Territory, the Donation Laws, \&c., \&c. (Olympia, 1855), 286, 297, 309-10, 395-96, 405. Accessed online February 16, 2012, through The Making of Modern Law: Primary Sources, 1620-1926. For studies on adoption and guardianship in the nineteenth century, see E. Wayne Carp, ed., Adoption in America: Historical Perspectives (Ann Arbor: University of Michigan Press, 2002); Michael Grossberg, Governing the Hearth: Law and the Family in Nineteenth-Century America (Chapel Hill: University of North Carolina Press, 1985); Norma Basch, "Marriage and Domestic Relations," in The Cambridge History of Law in America, vol. 2, The Long Nineteenth Century, 1789-1920, ed. Michael Grossberg and Christopher Tomlins (New York: Cambridge University Press, 2008), 245-79. For a discussion of "child rescue" and child welfare ideology in imperial contexts, see Shurlee Swain and Margot Hillel, Child, Nation, Race and Empire: Child Rescue Discourse, England, Canada, and Australia, 1850-1915 (New York: Manchester University Press, 2010).

13. For studies of indenture in the US West, see Katrina Jagodinsky, “Territorial Bonds: Indenture and Affection in Intercultural Arizona, 1864-1894," in On the Borders of Love and Power: Families and Kinship in the Intercultural American West, ed. David Wallace Adams and Crista DeLuzio (Berkeley: University of California Press, 2012), 380-412; Sondra Jones, “Redeeming the Indian': The Enslavement of Indian Children in New Mexico and Utah," Utah Historical Quarterly 67, no. 3 (1999): 220-41; Michael Magliari, "Free Soil, Unfree Labor: Cave Johnson Couts and the Binding of Indian Workers in California, 18501867," Pacific Historical Review 73, no. 3 (August 2004): 349-89; Stacey Leigh 
Smith, "California Bound: Unfree Labor, Race, and the Reconstruction of the Far West, 1848-1870" (PhD diss., University of Wisconsin-Madison, 2008).

14. Those seven children were Jack Judson, Dollie and Nellie Patterson, and John, Horace, Norah, and Daniel McClanahan (also spelled McLellehan); see Phoebe Goodell Judson, with foreword provided by Susan Armitage, A Pioneer's Search for an Ideal Home, by Phoebe Goodell Judson Who Crossed the Plains in 1853 and Became a Resident on Puget Sound before the Organization of Washington Territory (1925; Lincoln: University of Nebraska Press, 1984), 114-15, 195-97, 210-13, 231-32. The 188 o federal census does not include Jack but lists Dollie 17, Nellie 14, John 13, Horace 11, Norah 9, and Daniel 7; all are marked as "W" for white, and the word "adopted" is written in to enumerate their relationship to the household of Phoebe and Holden Judson in Lynden, Washington; see the Tenth Census of the United States, 1880: Lynden, Whatcom County, Washington.

15. In addition to Margaret D. Jacobs, White Mother to a Dark Race: Settler Colonialism, Maternalism, and the Removal of Indigenous Children in the American West and Australia, 1880-1940 (Lincoln: University of Nebraska Press, 2009), see James Brooks, Captives and Cousins: Slavery, Kinship, and Community in the Southwest Borderlands (Chapel Hill: University of North Carolina Press, 2002); Anne F. Hyde, Empires, Nations, and Families: A History of the North American West, 1800-1860 (Lincoln: University of Nebraska Press, 2011); Victoria Smith, Captive Arizona, 1851-19oo (Lincoln: University of Nebraska Press, 2009).

16. Margaret D. Jacobs, "Maternal Colonialism: White Women and Indigenous Child Removal in the American West and Australia, 1880-1940," Western Historical Quarterly 36, no. 4 (Winter 2005): 453-76.

17. For a comparison of these views, see Katherine Ellinghaus, "Indigenous Assimilation and Absorption in the United States and Australia," Pacific Historical Review 75, no. 4 (2006): 563-85.

18. A review of 261 guardianship cases in Clallam, Island, Jefferson, King, Lewis, Pierce, San Juan, Skagit, Snohomish, Thurston, and Whatcom Counties (all counties on the Puget Sound) yielded only twenty-three cases that included Indian or métis wards. Given that these numbers do not reflect informal arrangements such as Phoebe Judson's, which included seven children in her case alone, that many cases fail to record racial-ethnic identity accurately or at all, and that cases like Nora Jewell's were found in criminal records rather than probate files, I am convinced that many more instances of indigenous child removal occurred in Washington Territory. Indicators that cases involved nonwhite children even where race was not mentioned included wards with no estate or property, wards with unnamed parents, and wards with no specified relationship to the petitioner. 
19. Pierce County Probate Case no. 61, Susan Suckley (1863), Washington State Archives Puget Sound Regional Branch.

20. Charles Prosch, "Scarcity of White Women," Puget Sound Herald (Steilacoom WA), August 26, 1859. The violent effects of those mining camps on Native populations is described in Daniel P. Marshall, "No Parallel: American MinerSoldiers at War with the Nlaka'pamux of the Canadian West," in Parallel Destinies: Canadian-American Relations West of the Rockies, ed. John M. Findlay and Ken S. Coates (Seattle: University of Washington Press, 2002), 39-71.

21. On Ezra Meeker and Puyallup Indians, see Harmon, Indians in the Making, 145-51; as well as Ezra Meeker, The Tragedy of Leschi (Seattle: Historical Society of Seattle and King County, 1980). For the Prosch family without Susan Suckley, see Eighth Census of the United States, 1860: Steilacoom, Pierce County, Washington; Ninth Census of the United States, 1870: Olympia, Thurston County, Washington; Tenth Census of the United States, 1880: Seattle, King County, Washington. Due to frequent name changes and misspelling in legal records, browsing census records proved the most effective way to search for more information on the families discussed here. Many children, like Susan Suckley, appear only in probate records and cannot be traced further. Browsing federal and territorial census schedules between 1854 and 1920 reveals many Indian children in non-Indian households throughout the Puget Sound but also obscures blended families by sometimes alphabetizing surnames-making it difficult to identify households containing wards-and by either enumerating Indians separately even when they live in non-Indian households or failing to enumerate Indians or mark racial-ethnic categories.

22. See, for example, Commissioner of Indian Affairs to Edwin Eells, December 22, 1882, October 18, 1883, and October 25, 1883, series 1, RG 75, National Archives and Records Association, Pacific Northwest Branch. Unpublished material in the Puyallup Tribal Archive indicates that some historians and tribal members believe non-Indians in the Tacoma area used guardianship of Puyallup minors to transfer allotted tribal lands into non-Indian ownership in the late nineteenth century. These allegations seem very plausible and could likely be proven through a careful comparison of probate and allotment records but are beyond the scope of this particular essay. Published work linking guardianship and allotment fraud is unknown to the author, but for other non-Indian strategies to obtain Puyallup allotments, see Harmon, Indians in the Making, 131-59.

23. Washington Territorial Census, 1881: Olympia, Thurston County.

24. Thurston County Probate Case no. 204, Mary Toary (1881), Washington State Archives Southwest Regional Branch.

25. Washington Territorial Census, 1881: Olympia, Thurston County.

26. See Jennifer Seltz, "Epidemics, Indians, and Border-Making in the 
Nineteenth-Century Pacific Northwest," in Bridging National Borders in North America: Transnational and Comparative Histories (Durham NC: Duke University Press, 2010), 91-115. For fluid identities, see John Lutz, "Making 'Indians' in British Columbia: Power, Race, and the Importance of Place," in Power and Place in the North American West, ed. Richard White and John Findlay (Seattle: University of Washington Press, 1999), 61-86; Lutz's insights apply to territorial Washington as well. A good article outlining Coast Salish mobility is the editor's introduction in Miller, Be of Good Mind, 1-29.

27. Judson, Search for an Ideal Home, 114-15.

28. Tenth Census of the United States, 1880: Lynden, Whatcom County, Washington; Washington Territorial Census, 1885: Thurston County; Thirteenth Census of the United States, 1910: Rochester, Thurston County, Washington; Jack Judson death certificate, Washington State Death Records, http://www .digitalarchives.wa.gov/Record/View/308bdoo87f211b546664061d821081aA, accessed April 2012.

29. Washington Territorial Census, 1889: Whatcom County; Nellie L. Patterson marriage certificate, Whitman Marriage Records, Washington State Archives, http://www.digitalarchives.wa.gov/Record/View/ac73b83ca63273b368cc 68548bfe7c66, accessed April 2012.

30. Judson, Search for an Ideal Home, 231-32.

31. Judson, Search for an Ideal Home, 231, 232.

32. Washington Territorial Census, 1885: Whatcom County; Thirteenth Census of the United States, 1910: Maple, Whatcom County, Washington; Fifteenth Census of the United States, 1930: Delta, Whatcom County, Washington; Horace Greeley McClanahan death certificate, Washington State Death Records, http:// www.digitalarchives.wa.gov/Record/View/d 3 f84a5e2ao18bfaf5a7812135bbb88b, accessed April 2012.

33. Judson, Search for an Ideal Home, 210-13, 231.

34. For more on those attitudes and the policies they influenced, see Victoria Freeman, "Attitudes toward 'Miscegenation' in Canada, the United States, New Zealand, and Australia, 1860-1914," Native Studies Review 16, no. 1 (2005): 41-69; Debra Thompson, "Racial Ideas and Gendered Intimacies: The Regulation of Interracial Relationships in North America," Social \& Legal Studies 18, no. 3 (2009): 353-71. On miscegenation in the North American West, see Peggy Pascoe, What Comes Naturally: Miscegenation Law and the Making of Race in America (New York: Oxford University Press, 2009).

35. Clallam County Probate Case no. 18, Matilda Reuny (1876), Washington State Archives Northwest Regional Branch.

36. Ninth Census of the United States, 1870: Port Townsend, Clallam County, Washington; Tenth Census of the United States, 1880: Clallam County, Washington; Washington Territorial Census, 1887: Clallam County. 
37. Jefferson County Probate Case no. 2122, Caroline Dunning (1864, 1874), Washington State Archives Northwest Regional Branch.

38. Thirteenth Census of the United States: 1910: Port Townsend, Clallam County, Washington; US Indian Census, 1911: Puyallup Jamestown Village, Washington; US Indian Census, 1912: Puyallup Jamestown Village, Washington.

39. Clallam County Probate Case No. 18, Celia Fitzgerald (1878), Washington State Archive Northwest Regional Branch.

40. Jefferson County Civil Case no. 921, Celia Fleming (1886), http://www .digitalarchives.wa.gov/Record/View/4d984bb8d2e38a52c148079ca43ff706, accessed April 2012.

41. Washington Territorial Census, 1885: Clallam County; Thirteenth Census of the United States, 1910: Sequim, Clallam County, Washington; US Indian Census, 1911: Puyallup Jamestown Village, Washington.

42. Data presented here were compiled from the Tenth Census of the United States, 1880: Clallam, Island, Jefferson, King, Lewis, Pierce, San Juan, Snohomish, Thurston, and Whatcom Counties. Clallam County included children in three métis households. Island County showed children in four white households, three métis households, and one Indian household. Jefferson County listed seven métis households and three white households with minor wards. King County, which includes Seattle, reported children in eighteen white households, seven Indian households, and four métis households. Lewis County reported only one Indian household with a minor ward. Pierce County included seven white and two métis homes with wards. San Juan County showed children of Indian mothers in six métis, two Native, and two white households. Thurston reported children in one of each of the three household categories. Whatcom County listed minor wards in six white, five métis, and one Indian household. The 1860 federal census proved too early in the settlement period to record any conclusive data, and the 1870 federal census enumerated race inaccurately and inconsistently, making the 1880 census the most practical nineteenth-century schedule to use for a base-line reading of informal guardianship arrangements. Readers should still note that enumerators recorded race and relationships discriminately and that these numbers represent only the minimum number of households practicing extralegal guardianship in 1880 .

43. For indigenous child removal practices increasingly institutionalized in the twentieth century, see David Wallace Adams, Education for Extinction: American Indians and the Boarding School Experience, 1875-1928 (Lawrence: University Press of Kansas, 1995); David Fanshel, Far from the Reservation: The Transracial Adoption of American Indian Children (Metuchen NJ: Scarecrow Press, 1972); Susan Devan Harness, Mixing Cultural Identities through Transracial Adoption: Outcomes of the Indian Adoption Project (Lewiston NY: Edwin Mellen Press, 2008); Marilyn Irvin Holt, Indian Orphanages (Lawrence: Uni- 
versity Press of Kansas, 2001). For an international perspective on the institutionalization of adopting children from marginalized communities, see Denise Cuthbert et al., “'That Was Then, but This Is Now': Historical Perspectives on Intercountry Adoption and Domestic Child Adoption in Australian Public Policy," Journal of Historical Sociology 23, no. 3 (2010): 427-52; Karen Dubinsky, Babies without Borders: Adoption and Migration across the Americas (New York: New York University Press, 2010); Diana Marre and Laura Briggs, eds., International Adoption: Global Inequalities and the Circulation of Children (New York: New York University Press, 2009).

44. For indigenous resistance to these practices, see Cathleen D. Cahill, Federal Fathers and Mothers: A Social History of the United States Indian Service, 1869-1933 (Chapel Hill: University of North Carolina Press, 2011); Lisa E. Emmerich, "Save the Babies!': American Indian Women, Assimilation Policy, and Scientific Motherhood, 1912-1918," and Margaret D. Jacobs, "Resistance to Rescue: The Indians of Bahapki and Mrs. Annie E. K. Bidwell," in Writing the Range: Race, Class, and Culture in the Women's West, ed. Elizabeth Jameson and Susan Armitage (Norman: University of Oklahoma Press, 1997), 393-409 and 230-51, respectively; K. Tsianina Lomawaima, They Called It Prairie Light: The Story of Chilocco Indian School (Lincoln: University of Nebraska Press, 1994); Louise Erdrich, "American Horse," in The Art of the Short Story, ed. Wendy Martin (Boston: Houghton Mifflin, 2006), 1014-23. See also the articles included in this issue. 